\title{
Cytological screening for cervical cancer and human papillomavirus in general practice
}

\author{
E Hiscock, G Reece
}

\begin{abstract}
In a retrospective study of cervical screening in a general practice in Birmingham 156 out of 1913 smears taken over three years showed some abnormality. Smears from 65 women showed severe non-specific inflammation, and 91 women had various grades of cervical intraepithelial neoplasia, of whom 53 were aged under 30 and 13 over 40 . Of 35 women with clinical evidence of human papillomavirus, 21 had normal results on cervical testing and 14 abnormal results.

The incidence of genital warts among sexually active young people is growing, but the association of human papillomavirus with abnormal cervical smears is not clear. The efficacy of screening in the United Kingdom must be improved by actively encouraging younger patients to attend for regular screening.
\end{abstract}

\section{Introduction}

Over the past few years controversial evidence has suggested that human papillomavirus is associated with the development of cervical cancer. Human papillomavirus 16 and 18 sequences have been found in a high proportion of cervical carcinomas. ${ }^{1}$ Cases of genital warts seen at clinics for sexually transmitted diseases in the United Kingdom have increased from 20334 in 1973 to 49884 in $1984 .{ }^{2}$ Exophytic condylomas have been reported in up to $6 \%$ of women with vulval warts, ${ }^{3.5}$ and genital warts are common in women who attend gynaecology clinics and clinics for sexually transmitted diseases. Numerous reports have attempted to link the incidence of human papillomavirus infection with abnormal results of cervical screening but we do not know of any reports of screening for cervical cancer and human papillomavirus in a general medical practice. ${ }^{6}$

Recent reports show that the overall death rate from cancer of the cervix has declined but the death rate in younger age groups has increased. Between 1968 and 1984 deaths from cervical cancer fell from $12 \cdot 53$ to $9 \cdot 10$ per 100000 , but in women aged under 30 they increased more than fourfold from 0.22 to 0.91 per 100000 . Further rises are predicted in this younger group, which will cause a decrease in the overall downward trend in mortality in the next 10 years unless effective intervention by cervical screening is undertaken. ${ }^{7 x}$

Several reports from different countries have shown that screening of the population has been followed by a decrease in the incidence of invasive disease. ${ }^{910}$ In 1964

Streetly Road Surgery, Erdington, Birmingham B23 7AH

E Hiscock, MB, principal $\mathrm{G}$ Reece, SRN, practice nurse

Correspondence to: Dr Hiscock. a large scale cervical cytological screening service was started in Britain; since then mortality from cervical cancer has declined at $1 \%$ a year. ${ }^{11} 12$

We report the findings of cervical screening in our general practice and give details of four women under 30 with grade III cervical intraepithelial neoplasia, three of whom had human papillomavirus infection.

\section{Patients and methods}

Our general practice is an inner city suburb of north Birmingham and has a list size of 9900 patients, of whom 3301 are women aged 16-65. Organised screening for cervical cancer was started in 1984 for all National Health Service patients who were:

Women aged 16-65 who were sexually active; those attending for maternity care, gynaecological conditions, or family planning consultations; and patients who on their own initiative requested the service.

All women who had not had a smear in the past five years were identified from the age-sex register of the practice and invited to attend for screening. ${ }^{13}$ Patients who had had an abnormal smear before January 1985 were also invited for rescreening; these patients are not reported on here. When personally approached few women declined the opportunity to have a smear test.

When the smear was taken the external genitalia were examined for any lesions and especially for genital warts and the appearance of the cervix was noted. Patients with visible warts were treated in the surgery with podophyllin. Patients reported to have severe non-specific inflammation or cervical intraepithelial neoplasia grade I were called for repeat smear tests at appropriate intervals, ${ }^{14}$ and subsequent smears were referred to a gynaecologist. Patients reported to have moderate dysplasia compatible with cervical intraepithelial neoplasia grade II were given repeat smear tests after three months and then referred for colposcopy. All patients with severe dysplasia found to be compatible with cervical intraepithelial neoplasia grade III were immediately sent to the gynaecological department of Birmingham Women's Hospital for colposcopy and biopsy. Any warts found on colposcopy were treated in the department of gynaecology with a laser.

\section{Results}

Of 1913 initial smears taken over three years, 156 showed some cytological abnormality (table I). The 65 cases of severe non-specific inflammation entailed many repeat smears, which showed no change over three years, and no microbiological cause of the inflammation was discovered. The remaining 91 smears showed cervical intraepithelial neoplasia, which was classified as grade I in 42 , grade II in 34 , and grade III in 15 . Five of the patients with cervical intraepithelial neoplasia grade III had not had a smear in 10 years, but in the 10 others smears had progressed from showing no abnormality or cervical intraepithelial neoplasia grade I to showing cervical intraepithelial neoplasia grade III in an average of 33 months, with a range from 4 months to 8 years.

Thirty five women had clinical evidence of human papillomavirus infection, of whom 21 had normal cervical smears. Of the remaining 14, two had had 
recurrent infections with herpes simplex virus. Colposcopy confirmed human papillomavirus infection in 10 women who had cervical intraepithelial neoplasia, six who showed viral effects on the cervical smear, and four who showed no viral effects; nine of these were aged under 40 and were symptomless. Of the 91 patients with cervical intraepithelial neoplasia, 22 were shown either clinically or colposcopically to have human papillomavirus infection (table II). In a further 30 cases the smear showed "viral effects"; these were later attributed to koilocytotic atypia.

Altogether 53 women were aged under 30 when cervical intraepithelial neoplasia was diagnosed ( 30 with grade I disease, 18 with grade II, and six with grade III), 12 were $30-35,13$ were $35-40$, and 13 were over 40 ; the average age of women with cervical intraepithelial neoplasia was 29.9 years

TABLE I-Results of initial cervical screening in women attending general practice, Fanuary 1985 to December $1987^{\star}(n=1913)$

\begin{tabular}{lr}
\hline & No \\
\hline Normal smear: & 1731 \\
Unrepeated & 5 \\
Viral effects evident & 21 \\
Genital human papillomavirus present & 63 \\
Severe non-specific inflammation: & 2 \\
Clinically normal & 39 \\
Genital human papillomavirus present & 3 \\
CIN grade I: & 27 \\
Clinically normal & 7 \\
Genital human papillomavirus present & 13 \\
CIN grade II: & 2 \\
Clinically normal & \\
Genital human papillomavirus present & \\
ClN grade III: & \\
Genitally normal &
\end{tabular}

$\mathrm{CIN}=$ Cervical intraepithelial neoplasia

*Results of repeat tests and of repeat smear tests for 52 women with cervical intraepithelial neoplasia discovered before January 1985 are not included.

TABLE II-Prevalence of human papillomavirus and cervical dysplasia in women attending general practice, Fanuary 1985 to December 1987

\begin{tabular}{|c|c|c|c|c|}
\hline \multirow[b]{2}{*}{ Results of cytological screening colposcopy } & \multicolumn{3}{|c|}{ Grade of cervical intraepithelial neoplasia } & \multirow{2}{*}{$\begin{array}{c}\text { Total } \\
(n=91)\end{array}$} \\
\hline & $I(n=42)$ & II $(n=34)$ & III $(n=15)$ & \\
\hline Cervical intraepithelial neoplasia only & 21 & 10 & 8 & 39 \\
\hline "Viral effects" on smear testing & 16 & $12^{\star}$ & 2 & 30 \\
\hline \multicolumn{5}{|l|}{ Clinical evidence of human papillomavirus: } \\
\hline Alone & & $4 \dagger$ & 1 & 5 \\
\hline With viral effects in smear & 3 & 3 & 1 & 7 \\
\hline \multicolumn{5}{|l|}{ Colposcopic evidence of human papillomavirus: } \\
\hline Alone & 2 & 1 & 1 & 4 \\
\hline With viral effects in smear & NA & 4 & 2 & 6 \\
\hline
\end{tabular}

NA $=$ Not available

* One patient had previously been infected with herpes simplex virus.

tOne patient had previously been infected with herpes simplex virus and human papillomavirus.

Four patients under the age of 30 with cervical intraepithelial neoplasia grade III were of particular interest. The first had had a normal smear in 1977, when she was 21 . A smear taken eight years later was graded as showing grade III disease; a biopsy showed invasive adenocarcinoma. She was treated by radical hysterectomy and vault radiotherapy early in 1986. The second patient was found at the age of 16 to have cervical intraepithelial neoplasia grade II, which had progressed to grade III by the next year. At the age of 14 she had suffered a protracted attack of cervical, vulvovaginal, perineal, and anal warts, which had been treated initially with podophyllin and later, after she was referred to a gynaecology clinic, with laser treatment. The third patient with cervical intraepithelial neoplasia grade III was 23 when her smear showed viral effects with cervical intraepithelial neoplasia grade II; seven months later this had progressed to grade III. Colposcopy showed grade II disease and human papillomavirus infection. She was given laser treatment. The fourth patient, a 29 year old mother of two, had had a cervical smear five years previously. A routine smear taken when she attended for family planning advice showed cervical intraepithelial neoplasia grade II, and three months later grade III disease was evident. Colposcopy found high grade disease and early invasion. After laser excision histological examination confirmed grade III disease with glandular atypia and human papillomavirus infection.

\section{Discussion}

For many years the NHS has been complacent about cervical screening in general practice: the onus has been on women to present themselves at clinics and doctors' surgeries for this service, and health authorities have provided only limited facilities in cytology laboratories for smears to be checked. Most of the 91 patients $(4.8 \%)$ found to have cervical intraepithelial neoplasia in this study would have been missed if they had not been actively encouraged to present for screening. In 87 of these women the neoplasia was found at an early stage, when treatment offers excellent results.

Condyloma acuminata of the cervix (exophytic condyloma) has been associated with characteristic findings of koilocytosis, dyskeratosis, and nuclear atypia on cytological examination. ${ }^{15}$ Human papillomavirus types 16 and 18 sequences have been found in a high proportion of cervical carcinomas and cases of cervical intraepithelial neoplasia; the human papillomavirus 16 sequence is reportedly more commonly found in invasive cervical cancers. Meanwell et al suggested that the cause of cervical cancer is mediated by age. ${ }^{5}$ Our study found clinical evidence of human papillomavirus infection in 35 women, and on colposcopy in a further 10. Most of these women were under 40 years old and had no symptoms of cervical intraepithelial neoplasia.

Five smears were reported as normal but showing probable viral effects, and 30 smears were reported as showing cervical intraepithelial neoplasia and probable viral effects. The exact relevance of viral effects in cervical intraepithelial neoplasia is not clear; these lesions need to be carefully studied by Southern blot analysis and hybridisation for a full understanding of genital warts.

Mortality from cervical cancer has a strong social class gradient, the highest rate being found in social classes III, IV, and V.? Patients in our practice are generally social classes III-V.

Pressure is growing for family practitioner committees to attempt a coordinated screening policy with cytology laboratories. The call and recall systems that are being introduced may produce more accurate figures for cervical disease. ${ }^{16}$ Nevertheless, the present complicated and bureaucratic system of remunerating general practitioners fails to encourage them to take cervical smears.

Though it is necessary to screen middle aged women, those cancers are currently not being identified until they are at an advanced stage, it is important not to become complacent about the younger age group. We strongly support the suggestion of Campion et al that all women whose cervical smear shows dyskaryotic cells should be referred for colposcopy, particularly as mortality in young women has increased appreciably. ${ }^{17}$ Our study shows that an age barrier cannot be placed on screening: 65 of the 101 women with cervical intraepithelial neoplasia $(3.4 \%$ of initial smears) were less than 35 years old. Furthermore the incidence of genital warts is increasing in young people at an alarming rate. Though it is not possible to predict the potential importance and magnitude of this disease in the long term in this young group, the present 
system does not allow for any monitoring. Screening should start much earlier if we are to prevent the untreatable cervical cancers in women over 40; extra pressure must be put on women at high risk so that they accept screening and attend when called. Many of these women are embarrassed about being examined; a large number adopt an ostrich approach and deny themselves routine tests through fear of an unfavourable diagnosis. Recall should be at least triennial if any difference in the mortality and morbidity from cancer of the cervix is to be achieved.

We thank Dr Jennifer Clay of the General Hospital, Birmingham, and Professor A O Osoba of the department of medical microbiology, Ibadan, Nigeria, for their invaluable help with this paper; Dr M Light and the staff of the cytology department of North Birmingham District Hospital; and $\mathrm{Mr}$ J A Jordan for his help with colposcopy, clinical follow up, and general advice.

1 Gissman L. Human papilloma virus DNA in genital tumours. In: Williams AO, O'Connor GT, De-The GB, Johnson CA, eds. Virus associated cancers in Africa. Lyons: International Agency for Research on Cancer, 1984:405-11. (IARC Scientific Publications No 63.)

2 Communicable Disease Surveillance Centre. Sexually transmitted disease surveillance in Britain: 1984. London: Public Health Laboratory Service, 1986
3 Walker PG, Colley NV, Grubb C, Tejerina A, Oriel JD. Abnormalities of the uterine cervix in women with vulval warts. Br f Vener Dis 1983;59:120-3.

4 Walker PG, Singer A, Dyson JL, Oriel JD. Natural history of cervical epithelial abnormalities in patients with vulval warts. $B r \mathcal{F}$ Vener $D$ is 1983;59:327-9.

5 Meanwell CA, Cox ME, Blackledge G, Maitland NJ. HPV 16 DNA in normal and malignant cervical epithelium: implications for the aetiology and behaviour of cervical neoplasia. Lancet 1987;i:703-7.

6 Standing P, Mercer S. Quinquennial cervical smears: every woman's right and every general practitioner's responsibility. Br Med f 1984;289:883.

7 Beral V Cancer of the cervix a STD infection? Lancet 1974; ; : 1037-40.

8 Beral V, Booth M. Predictions of cervical cancer incidence and mortality in England and Wales. Lancet 1986; ; 495 .

9 Boyes DA, Nichols TM, Millner AM, Worth AJ. Recent results from the British Columbia screening programme for cervical cancer. Am $\mathcal{f}$ Obstet Gynecol 1977;128:692-3.

10 Green GH. Cervical cancer and cytology screening in New Zealand. Brf Obstet Gynaecol 1978;85:881-6.

11 Anonymous. Cancer of the cervix: death by incompetence [Editorial]. Lancet 1985;ii:363-4.

12 Cook GA, Draper GJ. Trends in cervical cancer and carcinoma in Great Britain. Br f Cancer 1984;50:367-75.

13 Draper GJ. Screening for cervical cancer, revised policy. The recommendations of the DHSS committee on gynaecological cytology. Health Trends 1982;14:37-40.

14 Evans DMD, Hudson EA, Brown CL, et al. Report of the British Society for Clinical Cytology working party on terminology in gynaecological cytopathology. F Clin Pathol 1986;39:933-44.

15 Meisels A, Fortin R. Condylomatous lesions of the cervix and vagina. I. Cytologic patterns. Acta Cytol 1976;20:505-9.

16 Imperial Cancer Research Fund Committee. Organisation of a programme for cervical cancer screening. Br Med f 1984;289:894-5.

17 Campion MJ, Singer A, Mitchell HS. Complacency in the diagnosis of cervical cancer. Br Med f 1987;294:1337-9.

(Accepted 20 April 1988)

\section{BOOKS RECEIVED}

Accident and emergency

Emergency: A Guide for Ambulance Personnel. M Walsh, T Eddolls. (Pp 288; figs; 212.95 plastic cover.) London: Heinemann, 1988. ISBN 0-433-00002-3.

\section{Acquired immune deficiency}

syndrome

AIDS Prevention and Control. Invited presentations and papers from the World Summit of Ministers of Health on Programmes for AIDS Prevention. [London, 26-28 January 1988.] World Health Organisation and United King dom Government. (Pp 192; f12 paperback. Geneva: World Health Organisation/Oxford: Pergamon, 1988. ISBN WHO: 92-4-156115-7, Pergamon: 0-08-036142-0.

AIDS Therapeutics in HIV Disease. $M$ Youle, J Clarbour, P Wade, C Farthing. (Pp 176; 57.95 paperback.) Edinburgh: Churchill Livingstone, 1988. ISBN 0-443-04029-X

Kaposi's Sarcoma: a Text and Atlas. Ed G J Gottlieb, A B Ackerman. (Pp 344 figs and colour plates, £70.92.) Philadelphia: Lea and Febiger, 1988. ISBN $0-8121-1041-2$.

\section{Allergy}

Progress in Allergy. Vol 41. "Malaria Immunology." Ed P Perlmann, H Wigzell. Series editors $\mathrm{K}$ Ishizaka, P Kallös, P J Lachmann, B H Waks man. (Pp 384; figs; £119.10.) Basei: Karger, 1988. Distributed by Joh Wiley and Sons. ISBN 3-8055-4672-6.

\section{Alternative medicine}

Holistic First Aid: a Handbook for the Home. M Nightingale. (Pp 192; figs; £5.99 paperback.) London: Optima 1988. ISBN 0-356-15198-0.

Trance and Treatment. Clinical Uses of Hypnosis. H Spiegel, D Spiegel. ( $\mathrm{Pp}$ 400 ; figs; £15 paperback.) Washingto DC: American Psychiatric Press. 1988. Distributed by Cambridge University Press. ISBN 0-88048-264-8.

\section{Anatomy}

Aids to Anatomy. S Paterson-Brown, $\mathrm{R}$ Eckersley. (Pp 240; 27.50 paperback. Edinburgh: Churchill Livingstone, 1988. ISBN 0-443-03624-1
Biology

Intercellular and Intracellular Communication 3. "Receptors and Ligands in Psychiatry." Ed A K Sen, T Lee. General editor B Cinader. (Pp 608; figs; £75.) Cambridge: Cambridge University Press, 1988. ISBN 0-52130719-8.

Intercellular and Intracellular Communication 4 "Receptors and Ligands in Neurological Disorders." Ed A K Sen, T Lee. General editor B Cinader. Pp 352; £45.) Cambridge: Cambridge University Press, 1988. ISBN 0-521 30720-1.

\section{Community medicine}

Surveillance in Health and Disease. Ed W J Eylenbosch, N D Noah. (Pp 306; figs; £35.) Oxford: Oxford University Press, 1988, on behalf of the Commission of the European Communities. ISBN 0-19-261611-0.

\section{Computers in medicine}

Computer Applications in Psychiatry. J D Leiff. (Pp 448; £27.50.) Washington DC: American Psychiatric Press, 1988. Distributed by Cambridge University Press. ISBN 0-521-35009-3.

\section{Diabetes}

Diabetes Mellitus in Pregnancy: Principles and Practice. E A Reece, D R Coustan. (Pp 672; figs; £65.) New York: Churchill Livingstone, 1988. ISBN 0-443-08470-X.

\section{History of medicine}

The Discovery of Insulin. M Bliss. (Pp 256; 6 6.95 paperback.) London: Faber and Faber, 1988. ISBN 0-571. $15385-2$

\section{Immunology}

In Focus Series. "Complement." S K A Law, K B M Reid. Series editor D Male, D Rickwood. (Pp 82; figs; $£ 5.95$ paperback.) Oxford: IRL Press, 1988. ISBN 1-85221-061-3.

In Focus Series. "Immune Recognition." M J Owen, J R Lamb. Series editors D Male, D Rickwood. (Pp 84; figs; $£ 5.95$ paperback.) Oxford: IRI Press, 1988. ISBN 1-85221-062-1.

In Focus Series. "Lymphokines." A S Hamblin. Series editors D Male, D Rickwood. (Pp 82; figs; £5.95 paperback.) Oxford: IRL Press, 1988. ISBN 1-85221-055-9.

\section{Neurology}

Cases in Neurogenic Communicative Disorders. J P Dworkin, D E Hartman. Pp 424; figs; £16.50 paperback.) Boston: Little Brown, 1988. Distributed by Churchill Livingstone. ISBN 0-316-19751-3.

Classics in Developmental Medicine. No 2. "The Natural History of Cerebral Palsy." B Crothers, R S Paine. (Pp 288; figs; £18.) London: MacKeith Press, 1988. Distributed by Blackwell Scientific. ISBN 0-632-01789-9.

Institute of Psychiatry: Maudsley Monographs. No 31. "The Neuropathology of Temporal Lobe Epilepsy." C Bruton. Series editors G Russell, E Marley, P Williams. (Pp 176; figs; Press, 1988. ISBN 0-19-712155-1.

Nutrition

Nutrition and Metabolism in Patient Care. J M Kinney, K N Jeejeebhoy, G L Hill, O E Owen. (Pp 816; figs; £78.) Philadelphia: Saunders, 1988 vich. ISBN 0-7216-1156-7.

\section{Oncology}

Xanthines and Cancer: an Experimental Study of Tumour Inhibition. W J P Neish. (Pp 176; £17.50 paperback.) Aberdeen: Aberdeen University Press, 1988. ISBN 0-08-036399-7.

Orthopaedics

Practical Orthopaedic Exposures. R McRae. (Pp 176; figs; £45.) Edinburgh: Churchill Livingstone, 1987. ISBN 0-443-02972-5.

\section{Paediatrics}

Practical Social Work: "Child Sexual Abuse." D Glaser, S Frosh. Serie editor J Campling. (Pp 190;£15 hardback, £5.95 paperback.) London: Macmillan, 1988. ISBN hardback 0-333-43890-0, paperback 0-333$42891-9$.

\section{Pathology}

Basic Histology and Cytology for Medical Laboratory Scientists. A W Currie. ( $P$ 176; £12.95 paperback.) Edinburgh Churchill Livingstone, 1988. ISBN 0-443-03402-8.

Pharmacology

The Opiate Receptors. Ed G Pasternak. Series editor D B Bylund. Pp 520; figs; \$89.50. New Jersey: Humana, 1988. ISBN 0-89603-120-9.

\section{Physiology}

Soviet Scientific Reviews. Section F. "Physiology and General Biology Reviews. Vol 2. Neurophysiológy Part A." Ed T M Turpaev. Series editors V I Gol'danskii. R Z Sagdeev, M Lévy, et al. (Pp 368; figs; \$228.) London: et al. (Pp 368; figs; \$228.) London:
Harwood Academic Publishers, Harwood Academic P

\section{Psychiatry}

Animal Models of Psychiatric Disorders. "Selected Models of Anxiety, Depression and Psychosis." Volume and serie editors P Simon, P Soubrié, D Wildlocher. (Pp 204; figs; f81.40.) Basel: Karger, 1988. Distributed by Joh Wiley and Sons. ISBN 3-8055-4667-X.

\section{Psychology}

Contributions to Human Development. Vol 19. "The Construction of Objectivity: a New Look at the First Months of Life." R Melkman. Series editor J A Meacham. (Pp 144; £45.) Basel: Karger, 1988. Distributed by John Wiley and Sons. ISBN 3-8055-4746-3.

Human Nature. D W Winnicott. (Pp 204; $£ 8.95$ paperback.) London: Fre Association Books, 1988. ISBN 0-946960-96-8.

\section{Radiology}

Frontiers of Clinical Neuroscience. Vo 4. "Clinical Neuroimaging." Ed W Theodore. Series editors I BodisWollner, E A Zimmerman. (Pp 304 figs; \$62.50.) New York: Liss, 1988 Distributed by John Wiley and Sons. ISBN 0-8451-4503-7.

\section{Social services}

Data on Employment of Newly Qualified CQSW Holders: Part II-One Year On. Central Council for Education and Training in Social Work. (Pp 20; f1.50 paperback. Available from 